\title{
Overlay tool on therapeutic planning for anterior communicating artery aneurysms
}

\author{
Ferramenta Overlay para planejamento terapêutico em \\ aneurismas da artéria comunicante anterior
}

\author{
Herramienta Overlay para la planificación terapéutica en \\ aneurismas de la arteria comunicante anterior
}

\author{
Igor Pagiola ${ }^{1}$, Guilherme Brasileiro de Aguiar², Michel Eli Frudit ${ }^{3}$, \\ Henrique Carrete Júnior ${ }^{4}$
}

\begin{abstract}
1.MD. Médico da Disciplina de Neurorradiologia Intervencionista. Universidade Federal de São Paulo (UNIFESP). São Paulo-SP, Brazil.

2.MD, PhD. Professor da Disciplina de Neurocirurgia. Faculdade de Ciências Médicas da Santa Casa de São Paulo (FCMSCSP). São Paulo-SP, Brazil.

3.MD, PhD. Chefe da Disciplina de Neurorradiologia Intervencionista. Universidade Federal de São Paulo (UNIFESP). São Paulo-SP, Brazil.

4.MD, PhD. Chefe do Departamento de Diagnóstico por Imagem - DDI. Universidade Federal de São Paulo (UNIFESP). São Paulo-SP, Brazil.
\end{abstract}

\begin{abstract}
Background. Anatomical variation in the anterior communicating artery complex is one of the challenging points when choosing between endovascular or surgical approach to treat aneurysms in this region. Besides, this is the most common location for aneurysms. Here we present our diagnostic angiography image protocol using the overlay tool to fully understand the anatomical variation of this region which assists in the best therapeutic planning of lesions in this location. Method. The authors performed a review of available data regarding overlay reconstruction tool. Search was conducted via Pubmed and Scielo databases with "overlay tool AND cerebral angiography" as keywords. Articles considered relevant were included in this review, especially those which focused on essential aspects of this specific vascular malformation. Conclusion. The overlay tool from the Allura Xper FD20 (Philips, Best, Netherlands) is an incredible way to better understand the anatomical variation of this region with the fusion of both A1 segments in the same image.
\end{abstract}

Unitermos. Intracranial aneurysms; Subarachnoid hemorrhage; microsurgery

\begin{abstract}
Resumo
Introdução. A variação anatômica do complexo da artéria comunicante anterior é um dos pontos desafiadores na avaliação do tratamento dos aneurismas com abordagem endovascular ou cirúrgica nesta região. Além disso, este é o local mais comum para aneurismas. Apresentamos aqui nosso protocolo de imagem de angiografia diagnóstica utilizando a ferramenta de sobreposição para entender completamente a variação anatômica desta região que auxilia no melhor planejamento terapêutico das lesões nesta região. Método. Os autores realizaram uma revisão dos dados disponíveis sobre a ferramenta de reconstrução de sobreposição. A pesquisa foi realizada nas bases de dados Pubmed e Scielo com "overlay tool AND cerebral angiography" como palavras-chave. Os artigos considerados relevantes foram incluídos nesta revisão, especialmente aqueles que enfocavam aspectos essenciais dessa malformação vascular específica. Conclusão. A ferramenta de sobreposição do Allura Xper FD20 (Philips, Best, Netherlands) é uma maneira incrível de entender melhor a variação anatômica desta região com a fusão dos dois segmentos A1 na mesma imagem.
\end{abstract}

Keywords. aneurisma intracraniano; hemorragia subaracnóidea; microcirurgia 


\section{Resumen}

Introducción. La variación anatómica en el complejo de la arteria comunicante anterior es uno de los puntos desafiantes al evaluar el tratamiento de los aneurismas con abordaje endovascular o quirúrgico en esta región. Además, esta es la localización más común de aneurismas. Presentamos aquí nuestro protocolo de imágenes de angiografía de diagnóstico utilizando la herramienta de superposición para comprender completamente la variación anatómica de esta región que ayuda a la mejor planificación terapéutica de las lesiones en esta región. Método. Los autores realizaron una revisión de los datos disponibles con respecto a la herramienta de reconstrucción de superposición. La búsqueda se realizó a través de las bases de datos de Pubmed y Scielo con "overlay tool AND cerebral angiography" como palabras clave. En esta revisión se incluyeron los artículos considerados relevantes, especialmente aquellos que se centraban en aspectos esenciales de esta malformación vascular específica. Conclusión. La herramienta de superposición de Allura Xper FD20 (Philips, Best, Netherlands) es una forma increíble de comprender mejor la variación anatómica de esta región con la fusión de ambos segmentos $A 1$ en la misma imagen.

Palabras clave. aneurisma intracraneal; hemorragia subaracnoidea; microcirugía

Research developed at Disciplina de Neurorradiologia Intervencionista, Universidade Federal de São Paulo (UNIFESP). São Paulo-SP, Brazil.

\section{INTRODUCTION}

Anterior communicating artery complex (ACoA) is the most common site of cerebral aneurysms ${ }^{1}$. Besides, the rupture risk in smaller sizes aneurysm is higher when compared to lesions on another sites $^{2-4}$. Huge anatomical variation is present in this region ${ }^{5}$ and due to this fact, the treatment (endovascular or microsurgical) could be difficult if a complete understanding of the anatomical presentation had not been achieved yet ${ }^{6-10}$.

Sometimes, carotid angiography does not allow complete anatomical understanding of the arteries of the anterior communicating complex. This directly impacts therapeutic planning. The overlay tool allows the reconstruction and fusion of images from the two carotid arteries for a better definition of the local anatomy. Here 
we present our diagnostic angiography image protocol using the overlay tool to fully understand the anatomical variation of this region which assists in the best therapeutic planning of lesions in this location.

\section{METHOD}

The authors performed a review of available data regarding overlay reconstruction tool. Search was conducted via Pubmed and Scielo databases with "overlay tool AND cerebral angiography" as keywords. Articles considered relevant were included in this review, especially those which focused on essential aspects of this specific vascular malformation. We also screened article references for further relevant data. A statistical approach could not be conducted due to paucity of data, and therefore, a descriptive summary was performed.

This article was illustrated with cases from the author's service. Our institutional review board has approved this retrospective study. Individual patient consent was not required as data were collected in an anonymous manner and there was no risk to patients.

\section{Technique for Image Acquisition}

The diagnostic subtraction angiography (DSA) was done under local anesthesia via a transfemoral approach; using a 4F vascular sheath, a 4F vertebral or Simmons 2 diagnostic catheter was advanced into both intracranial internal carotid and vertebral arteries. Vessel and aneurysm features were 
analyzed via monoplane and 3D rotational acquisition angiography. After that, the overlay tool in the workstation computer of the Allura Xper FD20 machine (Philips, Best, Netherlands) was used to make the fusion of both carotids in the same image to analyze the anatomical presentation of the communicating artery complex and the relation between the aneurysms and the neck with anterior communicating complex. The images were analyzed and some of them are presented in this article.

\section{DISCUSSION}

The anterior communicating artery complex has an anatomy variation that can be challenging in aneurysm treatment for microsurgical clipping or endovascular approach. Because of that, patients with ACoA aneurysms need to be well investigated to fully understand the anatomic disposition and the relation between the aneurysm neck and both $A 1$ and $A 2$ segments.

As proposed by Pagiola et $\mathrm{al}^{5}$ in 2019 , the anatomical identification of the variants of the anterior communicating complex is essential for the correct therapeutic planning. In cases with evident asymmetry or agenesis of the A1 segment, the overlay provides a complete picture of the anatomy (Figures 1 and 2), and not just a unilateral view of the carotid system.

This is essential, for example, for planning hemorrhagic control in cases of inadvertent trans operative rupture. 
Figure 1. Carotid angiography to detect aneurysm in the anterior communicating artery complex. A: right internal carotid (frontal view) showing hypoplasia of segment A1; B: left internal carotid (frontal view) showing opacification of the anterior communicating complex and aneurysm; C: 3D reconstruction of the right carotid angiography; D: 3D reconstruction of the left carotid angiography; $\mathrm{E}$ : after using the overlay tool, with the merging of the 3D images, allowing the visualization of all the vessels of the anterior communicating complex.

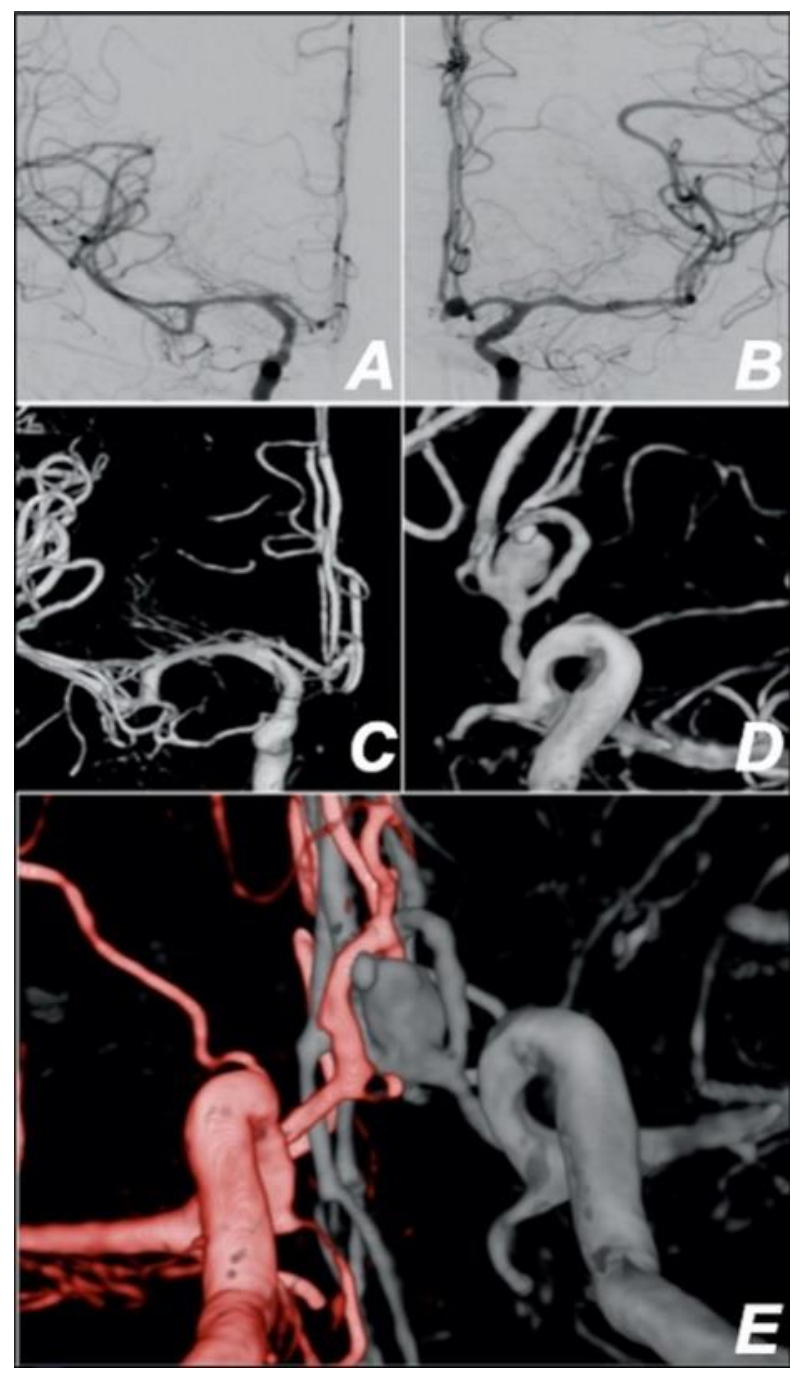


Figure 2. Carotid angiography to detect aneurysm in the anterior communicating artery complex. A: right internal carotid (frontal view) showing opacification of the anterior communicating complex and aneurysm; B: left internal carotid (frontal view) showing hypoplasia of segment $A 1 ; C$ : $3 D$ reconstruction of the right carotid angiography; D: 3D reconstruction of the left carotid angiography; $\mathrm{E}$ : after using the overlay tool, with the merging of the 3D images, allowing the visualization of all the vessels of the anterior communicating complex.

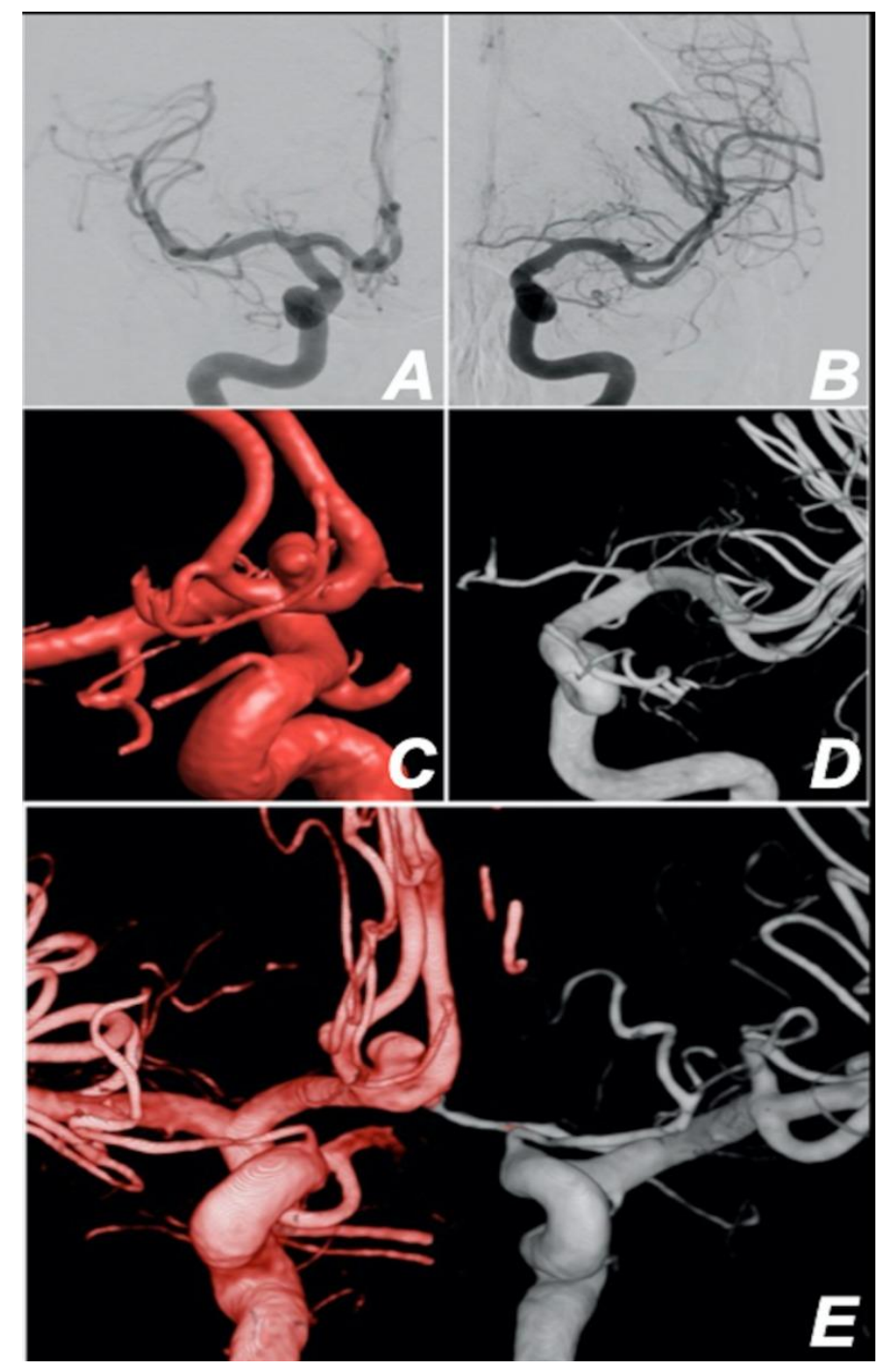

In addition to the asymmetry observed in the anterior communicating complex in more than $80 \%$ of cases $^{6,10,11}$, there is also the possibility of fenestrations, duplications of the anterior communicating artery and even the appearance of the azygos pattern ${ }^{11}$. 
All these aspects hinder the anatomical understanding of the region and can be better clarified with the use of the overlay tool. To produce the overlay image, we need to do one 3D acquisition for each artery (left and right ICA) with the same FD. After that, the tool "overlay" is chosen in the workstation and the fusion of both 3D is done by the Philips machine.

It seems that the overlay tool could help to better understand this complex region to propose the best treatment option. This has already been described but it is important to assess both carotid, even if the contralateral A1 segment is hypoplastic in non-invasive studies. With this tool, the anatomic configuration might be completely understood so that the best technical approach can be chosen, however, further studies are needed.

\section{CONCLUSION}

The overlay tool from the Allura Xper FD20 (Philips, Best, Netherlands) is an incredible way to better understand the anatomical variation of this region with the fusion of both A1 segments in the same image. This is essential for the correct therapeutic planning, whether it might be microsurgical or endovascular. Further studies are needed to better evaluate this tool in this specific aneurysm site.

\section{REFERENCES}

1. Kassell NF, Torner JC, Haley EC Jr, Jane JA, Adams HP, Kongable GL. The International Cooperative Study on the Timing of Aneurysm Surgery. Part 1: Overall management results. J Neurosurg 1990;73:18-36. https://doi.org/10.3171/jns.1990.73.1.0018 
2.Bijlenga $P$, Ebeling $C$, Jaegersberg $M$, Summers $P$, Rogers $A$, Waterworth $A$, et al. Risk of rupture of small anterior communicating artery aneurysms is similar to posterior circulation aneurysms. Stroke 2013;44:3018-26. https://doi.org/10.1161/STROKEAHA.113.001667

3. Mira JM, Costa FA, Horta BL, Fabião OM. Risk of rupture in unruptured anterior communicating artery aneurysms: meta-analysis of natural history studies. Surg Neurol 2006;66(Suppl 3):S12-9. https://doi.org/10.1016/j.surneu.2006.06.025

4. Heiskanen O. Risk of bleeding from unruptured aneurysm in cases with multiple intracranial aneurysms. J Neurosurg 1981;55:524-6. https://doi.org/10.3171/jns.1981.55.4.0524

5. Pagiola I, Mihalea C, Caroff J, Ikka L, Chalumeau V, Yassuda T, et al. Flow diversion treatment of aneurysms of the complex region of the anterior communicating artery: which stent placement strategy should 'I' use? A single center experience. J Neurointerv Surg 2019;11:111822. https://doi.org/10.1136/neurintsurg-2019-014858

6. Hernesniemi J, Dashti R, Lehecka M, Niemelã M, Rinne J, Lehto $H$, et al. Microneurosurgical management of anterior communicating artery aneurysms. Surg Neurol 2008;70:8-29. https://doi.org/10.1016/j.surneu.2008.01.056

7.Smith GA, Dagostino P, Maltenfort MG, Dumont AS, Ratliff JK. Geographic variation and regional trends in adoption of endovascular techniques for cerebral aneurysms. J Neurosurg 2011;114:1768-77. https://doi.org/10.3171/2011.1.JNS101528

8. Molyneux AJ, Kerr RS, Yu LM, Clarke M, Sneade M, Yarnold JA, et al. International subarachnoid aneurysm trial (ISAT) of neurosurgical clipping versus endovascular coiling in 2143 patients with ruptured intracranial aneurysms: a randomised comparison of effects on survival, dependency, seizures, rebleeding, subgroups, and aneurysm occlusion. Lancet 2005;366:809-17. https://doi.org/10.1016/S01406736(05)67214-5

9.Pierot L, Spelle L, Vitry F, ATENA Investigators. Immediate clinical outcome of patients harboring unruptured intracranial aneurysms treated by endovascular approach: results of the ATENA study. Stroke 2008; 39:2497-504.

https://doi.org/10.1161/STROKEAHA.107.512756

10.Cognard C, Pierot L, Anxionnat R, Ricolfi F, Clarity Study Group. Results of embolization used as the first treatment choice in a consecutive nonselected population of ruptured aneurysms: clinical results of the Clarity GDC study. Neurosurgery 2011;69:837-42. https://doi.org/10.1227/NEU.0b013e3182257b30

11. Makowicz G, Poniatowska R, Lusawa M. Variants of cerebral arteries - anterior circulation. Pol J Radiol 2013;78:42-7. https://doi.org/10.12659/PJR.889403 